\title{
MENGIDENTIFIKASI MINAT BAKAT SISWA SEJAK USIA DINI DI SD ADIWIYATA
}

\author{
Indah Ayu Anggraini ${ }^{1}$, Wahyuni Desti Utami ${ }^{2}$, Salsa Bila Rahma ${ }^{3}$ \\ Universitas Muhammadiyah Tangerang \\ zehidaafiera08@gmail.com,wdestiutami@gmail.com
}

\begin{abstract}
This paper is the result of a descriptive qualitative research that aims to find out about the interests and talents of students in elementary schools. The results of this study indicate that interests and talents refer to the results of students' understanding. The strategy applied by classroom teachers is to provide material interests and talents into learning materials, choose the right methods and media, remedial, build communication, set an example, give appreciation and knowledge, identify and choose assistance programs. Class teacher competence still needs to be improved so that students' interests and talents in learning can be better than before.
\end{abstract}

Keywords: Talent Interests, Elementary Students, Learning Design, Reading

\begin{abstract}
Abstrak: Tulisan ini adalah hasil penelitian hasil kualitatif deskriptif yang bertujuan untuk mengetahui tentang minat dan bakat siswa di Sekolah Dasar. Hasil penelitian ini menunjukkan bahwa minat dan bakat mengacu pada hasil pemahaman peserta didik. Strategi yang diterapkan guru kelas adalah dengan memberikan materi minat dan bakat kedalam materi pembelajaran, memilih metode dan media yang tepat, remedial, membangun komunikasi, memberikan teladan, memberi apresiasi dan pengetahuan, mengidentifikasi dan memilih progam bantuan. Kompetensi guru kelas masih perlu ditingkatkan agar minat dan bakat siswa dalam belajar bisa lebih baik dari sebelumnya.
\end{abstract}

Kata Kunci: Minat Bakat, Siswa SD, Desain Pembelajaran, Membaca

\section{PENDAHULUAN}

Minat menurut Sardiman, dikutip dari buku 1990 milik Sardiman. Ia menyatakan bahwa minat akan terlihat dengan baik jika mereka bisa menemukan objek yang disukai dengan tepat sasaran serta berkaitan langsung dengan keinginan tersebut. Minat juga harus memiliki objek yang jelas untuk mempermudah kemanaarahnya seseorang harus bersikap dan menuju objek yang tepat.

Islamika : Jurnal Keislaman dan Ilmu Pendidikan

Volume 2, Nomor 1, Januari 2020; 161-169

https:// ejournal.stitpn.ac.id/index.php/islamika 
Menurut Shaleh Abdul Rahman dalam bukunya psikologi suatu pengantar dalam perspektif islam, menjelaskan bahwa minat adalah suatu kecenderungan untuk memberikan perhatian dan bertindak terhadap orang, aktivitas atau situasi yang menjadi objek dari minat tersebut dengan disertai perasaan atau gembira. ${ }^{1}$

Bakat Menurut William B. Michael (suryabrata 1995) Bakat merupakan kapasitas pada diri seseorang dalam melakukan tugasnya dan melakukan dengan pengaruh dan latihan yang dijalaninya ${ }^{2}$

Menurut Bigham (1968) Bakat sebagai kondisi atau kemampuan yang dimiliki seseorang yang memungkinkan dengan suatu latihan khusus dapat memperoleh suatu kecakapan, pengetahuan dan keterampilan khusus.

\section{METODE PENELITIAN}

\section{Jenis Penelitian}

Jenis penelitian yang digunakan adalah penelitian deskriptif kualitatif.

\section{Waktu dan Tempat Penelitian}

Penelitian dilaksanakan selama hampir 1 minggu yaitu dari tanggal 13 November sampai 21 November 2019 di SDN Periuk 6

\section{Subjek Penelitian}

Subjek penelitian merupakan seseorang atau sesuatu yang darinya diperoleh keterangan dan untuk selanjutnya disebut informan. Penelitian ini juga mengambil informan kunci. Maka dalam subjek penelitian ini adalah guru dan siswa Sekolah Dasar Negeri Periuk 6. Yang didasarkan pada alasan guru dan siswa merupakan pelaksan utama dalam pembelajaran.

\section{Data, Instrumen, dan Teknik Pengumpulan Data}

Teknik pengumpulan data dengan menggunakan instrumen observasi, wawancara, dan dokumentasi. Teknik pengumpulan data yang bermacam-macam 
(triangulasi data), pengumpulan data dilakukan secara terus-menerus sampai datanya jenuh.

\section{Teknik Analisis Data}

Teknik analisis data pada penelitian ini menggunakan metode analisis deskriptif kualitatif. Analisis data kualitatif dengan proses mencari dan menyusun secara sistematisdata yang diperoleh dari hasil wawancara, catatan lapangan, dan bahan-bahan lain.

Teknik analisis data penelitian di lakukan dengan reduksi data enyajian data dan penarikan kesimpulan. Reduksi data yaitu proses pemilihan, pemutusan perhatian pada penyederhanaan, pengabstrakan, dan transformasi data "kasar" yang muncul dari catatan di lapangan. Penyajin data yaitu penyusunan sekelompok informasi yang memberi kemungkinan adanya penarikan kesimpulan dan pengembalian tindakan. Penarikan kesimpulan yaitu di ungkapkan makna dari data yang di kumpulkan.

\section{HASIL DAN PEMBAHASAN}

SDN Periuk 6 merupakan salah satu SD Adiwiyata yang ada di Kecamatan Periuk. SDN Periuk 6 telah memiliki akreditasi A. Penetapan lokasi penelitian di SDN Periuk 6 ini dikarenakan salah satu sekolah yang sudah menggunakan kurikulum 2013 tetapi masih kurangnya minat bakat siswa dalam belajar.

Hasil penelitian menunjukan bahwa minat bakat siswa yang masih sangat kurang dalam proses pembelajaran di karenakan adanya sebuah kesulitan dalam menerapkan nya pada diri siswa. Jadi sebelum guru memulai atau melakukan proses belajar, ia harus mengetahui minat bakat dari siswa tersebut.

Manfaat yang akan diperoleh oleh guru dalam mengidentifikasi minat bakat siswa dalam proses pembelajaran yaitu guru bisa mengetahui minat dan bakat siswa itu seperti apa, dan dari situ guru mampu menggembangkan potensi mereka seperti menjadi lebih aktif, kreatif, siswa dapat berpikir lebih ilmiah dan karakter siswa semakin di bentuk 
Selama 4 tahun pertama dari kehidupannya, perkembangan intelektual anak sama banyaknya dengan perkembangan selama 13 tahun berikut. Karena itu, menggali dan mengembangkan potensi mereka sejak dini dengan menstimulasi kebiasaan anak sejak kecil. Banyak ahli yang mengatakan bahwa kapasitas belajar anak yang terbentuk dalam masa ini akan menjadi landasan bagi semua proses belajar pada masa yang akan datang.

Keterlibatan orang tua dalam belajar anak mempunyai peranan dan kontribusi yang akan bermakna sebagai motivasi bagi anak. Rangsangan akan membentuk cabang-cabang otak sebanding dengan yang kita berikan. Pengetahuan dan pengalaman anak juga akan semakin kaya. Perlu juga dibentuk kebiasaan belajar atau tradisi berprestasi dalam keluarga. Dengan pembiasaan positif, seperti membaca buku ensiklopedia, buku pelajaran, buku cerita. Orang tua dan guru harus mengetahui potensi anak terlebih dahulu. Stimulasi yang sesuai dengan bakat dan minat anak pun bisa membuat tumbuh kembang mereka optimal karena dijalani tanpa paksaan. Munculnya potensi (kemampuan) anak memang bergantung pada rangsangan yang diberikan orang tua dan lingkungan yang mendukung. Karena itu, wajib bagi orang tua dan guru untuk menggali sekaligus mengembangkan potensi anak sejak dini. Makin dini anak menerima stimulasi akan makin baik.

Munculnya potensi (kemampuan) anak memang bergantung pada rangsangan yang diberikan orangtua dan lingkungan yang mendukung. Karena itu, wajib bagi orangtua dan guru untuk menggali sekaligus mengembangkan potensi anak sejak dini. Makin dini anak menerima stimulasi akan makin baik.

Bakat memungkinkan seseorang mencapai prestasi tertentu dalam bidang tertentu. Akan tetapi diperlukan latihan, pengetahuan, pengalaman dan dorongan atau motivasi agar dapat tersebut dapat terwujud. Misalnya seseorang memiliki bakat menggambar, jika ia tidak pernah diberi kesempatan untuk mengembangkan, maka bakat tersebut tidak akan tampak ${ }^{3}$

${ }^{3}$ Saifudin, (2013). Definisi Bakat Dan Ciri-ciri Anak Berbakat 


\section{Pengembangan Bakat}

Bakat merupakan talenta untuk membangun kekuatan pribadi anak dimasa mendatang. Seseorang dikatakan mempunyai bakat terhadap kegiatan tertentu ketika ia merasakan kelegaan dan kenikmatan serta apabila gembira mengerjakannya dan membicarakannya, juga ketika ia berusaha atas dasar keinginannya untuk menampakkan seluruh tenaganya guna mencapai hal itu. Pengalaman menyinari bakat dan bakat didapat melalui belajar, baik berhubungan dengan mapel, permainan, pikiran dalam menjawab teka-teki ${ }^{4}$

Menurut C. Semiawan dkk dalam buku karangan Yudrik Jahja mendefinisikan bahwa bakat merupakan kemampuan bawaan yang merupakan potensi yang masih perlu dikembangkan atau dilatih.Pada dasarnya setiap manusia memiliki bakat pada suatu bidang tertentu dengan kualitas yang berbeda-beda.Bakat yang dimiliki oleh seseorang dalam bidang tertentu memungkinkannya mencapai prestasi pada bidang ini.Untuk itu diperlukan adanya latihan, pengetahuan, dorongan asosiasi dan moral (so-cial and moral support) dari lingkungan yang terdekat.Bakat yang ada bersifat akademik dan non-akademik.Bersifat akademik berhubungan dengan pelajaran dan bersifat non-akademik berhubungan dengan bakat dalam bidang sosial, seni, olahraga, serta kepemimpinan.

\section{Karakteristik Anak Berbakat}

Seorang anak berbakat biasanya dapat diidentifikasi secara umum melalui karakteristik

sebagai berikut:

1) Anak akan dengan mudah melakukan/mempelajari hal yang menjadi bakatnya tanpa ada campur tangan orang lain.

2) Anak akan senang/tak merasa terbebani untuk berlatih atau mencoba berkreasi dengan lebih chal-lenging. Bila bermain piano maka ia akan menyukai improvisasi. Senang melakukan eksperimen dengan menggabung-gabungkan sendiri, misalnya untuk lagu-lagu klasik bila dimainkan menggunakan beat pop/jazz/dangdutan.

\footnotetext{
${ }^{4}$ Hurlock, E.B. (1980). Psikologi Perkembangan Suatu Pendekatan Sepanjang Rentang Kehidupan. Jakarta: Erlangga
} 
3) Anak menyukai kreasi dan memiliki apresiasi (pemahaman dan penghargaan) yang tinggi terhadap hal yang menjadi bakat dan minatnya. Apabila ia menyukai aktivitas bermain piano, maka ia juga menyukai kegiatan mendengarkan orang lain bermain piano. Ia dapat pula melihat/menganalisa secara detail teknik bermain piano yang dilakukan orang lain maupun lagunya.

4) Anak tidak pernah merasa bosan dan selalu "mencari” kegiatan yang berhubungan dengan keberbakatannya.Ia memiliki motivasi internal yang sangat kuat.

5) Anak biasanya mempunyai kemampuan pada bidang tersebut yang amat menonjol sekali

dibanding dengan kemampuan lainnya.

6) Tanpa digali kemampuannya sudah muncul sendiri

\section{APAKAH ITU POTENSI, MINAT DAN BAKAT?}

Potensi adalah kemampuan yang mempunyai kemungkinan untuk dikembangkan, kekuatan, kesanggupan dan daya. Berpotensi artinya memiliki potensi. Menurut kamus bahasa Indonesia, potensi adalah kesanggupan, daya, kemampuan untuk lebih berkembang. Setiap orang memiliki potensi, dan tentu berbeda setiap apa yang dimiliki antara satu orang dengan orang lain. Potensi adalah hal-hal spesifik yang ada pada diri anak, yang tampak lebih bila dibandingkan dengan anak seusianya. Anak-anak pada dasarnya kreatif, mereka mempunyai ciri-ciri individu sebagaimana yang lain seperti memiliki rasa ingin tahu yang besar, senang bertanya, dan memiliki imajinasi yang tinggi. Anak yang memiliki potensi yang berbeda dengan teman seusianya sering disebut anak yang berbakat.

Minat adalah dorongan yang kuat bagi seseorang untuk melakukan segala sesuatu yang menjadi keinginannya. Minat merupakan faktor yang dapat mengarahkan bakat dan keberadaannya merupakan faktor utama dalam pengembangan bakat. Kata minat lebih menggambarkan motivasi, yang mempengaruhi perhatian, berpikir dan berprestasi.

Minat dapat dibedakan menjadi dua yaitu minat pribadi (personal interest) dan minat situasional. Minat pribadi (personal interest), yaitu ciri pribadi individu 
yang relatif stabil. Minat pribadi ditujukan pada suatu kegiatan atau topik yang spesifik (misalnya minat pada olah raga, ilmu pengetahuan, musik, tarian, komputer, dan lain-lain). Sedangkan minat situasional, yaitu minat yang ditumbuhkan oleh kondisi atau faktor lingkungan, misalnya peran pendidikan formal, informasi yang diperoleh melalui buku, internet atau televisi.

Bakat dapat diartikan sebagai kemampuan bawaan, sebagai sebagai potensi yang masih perlu dikembangkan dan dilatih agar dapat terwujud. Bisa disebut juga sebagai achievement, capacity dan aptitude.

Adapun ciri-ciri bakat sebagai berikut :

a. Memiliki kemampuan diatas rata-rata

b. Daya kreatifitas yang tinggi

c. Memiliki tanggung jawab atau pengikatan diri terhadap tugas

Mengenal bakat anak dalam bidang akademis dapat diketahui dengan melihat nilai rapor. Cara menemukan bakat menurut menurut Renzulli ( Gunarsa \& Gunarsa, 1991) yaitu :

1. Pendekatan psikometri : yaitu tekhni pendekatan yang untuk melakukan penilaian dan pengukuran aspek psikis

2. Hal -hal yang terlibat dalam perkembangan

3. Penampilan yang meliputi prestasi dan perilaku

4. Pendekatan sosiometri melalui cara tidak formal oleh lingkungan sosial ${ }^{5}$ Indentifikasi bakat anak merupakan hal yang sangat penting dilakukan. Hal ini dikarenakan setiap anak memerlukan program pendidikan yang sesuai dengan bakat mereka masing-masing sehingga dapat mengembangkan dan menggunakan bakat mereka secara maksimal.

Dengan mengenali bakat anak sedini mungkin maka orang tua tentunya akan terasa terbantu bila dapat mengenali potensi dan bakat anak karna orang tua dapat langsung mengarahkan dan membimbing agar bakat tersebut bis berkembang. Begitu pula dengan sang anak, anak menggali bakat serta potensi yang dimilikinya terasah lebih baik.

${ }^{5}$ Saifudi. (2013). Cara Mengenali Bakat Siswa Didik 
Dari paparan hasil penelitian diatas, dapat diamati bahwa guru sudah dapat mengidentifikasi minat bakat siswa dengan baik selama proses pembelajaran. Jika beberapa kendala diatas dapat diatasi dengan baik maka minat bakat siswa serta penggembangan potensi siswa juga akan lebih baik lagi.

\section{KESIMPULAN}

1. Guru menjadi inspirator bagi siswa dengan berbagai langkah seperti memberi contoh sikap keteladanan, menunjukkan keahliannya untuk dapat menginspirasi siswa

2. Guru sebagai observer dengan melakukan proses pengamatan kebiasaan dan kegemaran siswa, lalu mengkaji hasil pengamatan dengan berkonsultasi dengan wali kelas dan siswa yang bersangkutan.

3. Guru sebagai motivator.

4. Guru dengan berbagai pengalamannya selalu memberikan semangat kepada siswa untuk mengerjakan tugas dengan baik dan penuh dengan antusias dilakukan baik secara individual kepada peserta didik dan secara kelompok.

5. Bakat adalah kemampuan dasar seseorang untuk belajar dalam tempo yang relatif pendek dibandingkan orang lain, namun hasilnya justru lebih baik. Bakat merupakan potensi yang dimiliki oleh seseorang sebagai bawaan sejak lahir.

6. Minat ialah suatu proses pengembangan dalam mencampurkan seluruh kemampuan yang ada untuk mengarahkan individu kepada suatu kegiatan yang diminatinya.

\section{DAFTAR PUSTAKA}

Hafsoh, Siti. (2016).'Peran guru dalam mengembangkan bakat dan minat siswa pada pendidikan guru madrasah ibtidaiyah". Fakultas Ilmu Tarbiyah dan Keguruan. Universitas Islam Negeri Sunan Kalijaga Jogjakarta.

Komala. (2017). Stimulasi Melejitkan Potensi, Minat dan Bakat pada Anak Usia Dini. Saifudin. (2013). Cara Mengenali Bakat Siswa Didik.

Setiawan Samhis. (2019). Pengertian Bakat Menurut Para Ahli. 
Indah Ayu Anggraini, Wahyuni Desti Utami, Salsa Bila Rahma

Tiffany, (2018). Pengertian Minat Menurut Para Ahli.

Savitra, Khanza. (2018). Pengertian Bakat Menurut Para Ahli.

Saifudin, (2013). Definisi Bakat Dan Ciri-ciri Anak Berbakat.

Hurlock, E.B. (1980). Psikologi Perkembangan suatu Pendekatan Sepanjang Rentang Kehidupan. Jakarta: Erlangga.

Fitriani, Feti. (2016). Bakat Dan Minat Anak Usia Dini 